\title{
DEVELOPMENT OF A HABITAT SUITABILITY INDEX FOR THE NOBLE CRAYFISH ASTACUS ASTACUS USING FUZZY MODELLING
}

\author{
S. ZUTHER (1), H.K. SCHULZ (2), A. LENTZEN-GODDING (3), R. SCHULZ (2)
}

(1) Institute of Geoecology, Technical University Braunschweig, Langer Kamp 19c, D-38106 Braunschweig, Germany.

E-Mail: s.zuther@tu-bs.de

(2) Institute of Environmental Sciences, University Koblenz-Landau, Fortstr. 7, D-76829 Landau, Germany.

(3) Zoological Institute, Technical University Braunschweig, Fasanenstr. 3, D-38092 Braunschweig, Germany.

Reçu le 4 novembre 2004

Accepté le 14 février 2005

Received November 4, 2004

Accepted February 14, 2005

\begin{abstract}
A Geographic Information System (GIS) and fuzzy modelling were used to develop a habitat suitability index for the noble crayfish, Astacus astacus. The model is based on crayfish distribution data for the federal state Hesse, Germany, which had been recorded between 1988 and 1996. It includes 185 sites with noble crayfish in 126 watercourses. Official data on the morphological quality of surface waters recorded between 1996 and 1998 by order of the Ministry of Hesse for Environment, Rural Areas and Consumers Protection was used to describe the habitat features. One third of the crayfish sites was selected by chance to determine habitat properties significantly associated with crayfish occurrence by means of the Kolmogorov-Smirnoff test and frequency analysis. Meaningless associations were excluded based on expert knowledge. Five parameters related to the structure of the riverbed and the bankside were incorporated in the fuzzy model. The model was complemented by a number of parameters known to exclude the occurrence of the noble crayfish (e.g. pipes, concrete embankments). Finally, a habitat suitability index for every stretch of water in Hesse was calculated. The predictive power of the fuzzy model was tested on the remaining distribution data set for Astacus astacus. The habitat suitability index differed slightly but significantly $(p<0.001)$ between sites with and sites without crayfish occurrence. Fuzzy modelling proved to be useful for assessing habitat suitability with respect to crayfish, though further improvements of the model appeared to be necessary for a more reliable prediction of noble crayfish sites.
\end{abstract}

Key-words: Astacus astacus, fuzzy modelling, Germany, Geographic Information System (GIS), habitat suitability, stream structure, Water Framework Directive.

\section{DÉVELOPPEMENT D'UN INDICE DE QUALITÉ D'HABITAT POUR L'ÉCREVISSE NOBLE ASTACUS ASTACUS PAR MODÉLISATION FLOUE}

\section{RÉSUMÉ}

Un système d'information géographique (SIG) et un modèle de logique floue ont été utilisés pour développer un indice de qualité d'habitat pour l'écrevisse noble, Astacus astacus. Le modèle est basé sur les données de distribution des écrevisses de l'état fédéral 
de Hesse, Allemagne, enregistrées entre 1988 et 1996. II inclut 185 sites d'écrevisses nobles dans 126 cours d'eau. Les données officielles sur la qualité morphologique des eaux de surface enregistrées entre 1996 et 1998 sur ordre du ministère de Hesse pour l'environnement, les secteurs ruraux et la protection des consommateurs ont été utilisées pour décrire les caractéristiques des habitats. Un tiers des sites à écrevisses a été choisi par hasard pour déterminer les propriétés des habitats significativement associées aux occurrences des écrevisses à l'aide du test de Kolmogorov-Smirnoff et l'analyse des fréquences. Les associations insignifiantes ont été exclues sur la base des connaissances des experts. Cinq paramètres décrivant les structures du lit des rivières et des berges ont été importés dans le modèle de logique floue. Ce dernier a été complété par un certain nombre de paramètres connus pour exclure les occurrences des écrevisses nobles (ex. tuyaux, remblais bétonnés). Finalement, l'indice de qualité d'habitat a été calculé à chaque partie d'eau. Le pouvoir de prédiction du modèle de logique floue a été testé sur le reste des données de dispersion d'Astacus astacus. L'indice de qualité d'habitat diffère légèrement mais significativement $(p<0.001)$ entre sites avec et sites sans écrevisses. Le modèle de logique floue a prouvé son utilité pour l'évaluation de qualité d'habitat des écrevisses, cependant ce modèle pourra être amélioré pour augmenter la fiabilité de prédiction des territoires à écrevisses nobles.

Mots-clés: Astacus astacus, modélisation floue, Allemagne, système d'information géographique (SIG), qualité d'habitat, structure d'eau, directive cadre eau.

\section{INTRODUCTION}

Until the end of the $19^{\text {th }}$ century the noble crayfish Astacus astacus was widely distributed in Central Europe and an important economical factor for the fishery in Germany (BLANKE, 1998). During the twentieth century stocks of European indigenous crayfish species were diminished by the crayfish plague, competition with introduced non-indigenous crayfish species and habitat deterioration (BLANKE, 1998; MEINEL and MOCK, 2001). Relict populations of the noble crayfish are protected by European and German conservation laws (BLANKE, 1998; VIGNEUX et al., 2002). Due to an increasing interest in indigenous crayfish, a number of conservation and restocking measures are conducted in Germany.

Four different crayfish species, the two indigenous species Astacus astacus and Austropotamobius torrentium and the two non-indigenous species Orconectes limosus and Pacifastacus leniusculus were found in the German federal state Hesse with an area of $21,114 \mathrm{~km}^{2}$ (MEINEL and MOCK, 2001). Astacus astacus is still the most frequent crayfish species with more than 200 recorded populations. Hesse is therefore the federal state with the highest density of known noble crayfish populations in Germany (SCHULZ, 2000). This situation is probably determined by a relatively good condition of many water bodies in Hesse and a still restricted distribution of non-indigenous crayfish species.

The noble crayfish is assumed to be a bioindicator for a reasonable chemical, yet good structural quality of streams and lakes. This species is mostly found in waters with low trophic level (SKURDAL and TAUGBØL, 1994) and a natural or semi-natural structure of the riverbed and bank (BOHL, 1989; TREFZ and GROB, 1996; BLANKE, 1998; BOHL, KELLER and OIDTMANN, 2001). According to findings by SKURDAL et al. (1988), BOHL (1989), BLANKE (1998), ENGLUND and KRUPA (2000) and BROQUET, THIBAULT and NEVEU (2002), structural diversity of the habitat is essential to support a viable population. For example, during its life cycle the noble crayfish is dependent on a broad variation of depths and substrate types (TREFZ and GROB, 1996; BLANKE, 1998). SMITH et al. (1996) emphasized the importance of vertical banks, tree roots, macrophytes and bankside vegetation for the occurrence of Austropotamobius pallipes populations in streams. Furthermore, land-use patterns in the surrounding of lakes and rivers are potential factors 
influencing the distribution of crayfish stocks (BOHL, 1989; SCHULZ, SMIETANA and SCHULZ, 2002).

With regard to the federal state Hesse, structural characteristics of all rivers and streams have been assessed from 1996 to 1998 and described in qualitative expressions (BLANK et al., 2000). Although extensive information is available in a digitised format ready to use in a Geographic Information System (GIS), it has not yet been exploited to describe the stream habitat quality for aquatic species. Semi-quantitative and qualitative descriptions are not suited for an exact ecological model. Furthermore, a certain amount of impreciseness and subjectivity is inherent in classifications of real ecological phenomena. A number of authors propose the use of fuzzy logic for ecological modelling (BOSSERMAN and RAGADE, 1982; SALSKI, 1992; SCHULTZ and WIELAND, 1995; WIELAND, LUTZE and HOFFMANN, 1996; WIELAND, 1997; LUTZE, WIELAND and SCHULTZ, 1999). Fuzzy logic is able to cope with the properties of the existing data. For this reason, its application seems to be best suited for modelling the habitat quality in the present case. SCHULTZ and WIELAND (1995) and WIELAND (1997) provide good examples for using fuzzy elements in habitat modelling describing the habitat suitability with regard to the barn owl Tyto alba and the great bustard Otis tarda. These studies indicate the broad range of applications of this method due to its ability to imitate human decision-making.

In the fuzzy set theory nothing is evaluated as really precise. It takes into account a degree of uncertainty in estimations and measurements, which humans can include in their decision process, but machines or computers cannot. Human decision-making is fuzzy, and fuzzy-logic tries to imitate it to produce more human-like results requiring less information (BOSSERMAN and RAGADE, 1982; SALSKI, 1992; TRAEGER, 1994; PIEGAT, 2001). In classical set theory an element either belongs to a set or it does not. The membership to a set can only be 1 or 0 . According to the fuzzy set theory an element can also be a member of a set to a certain degree and memberships can take values within the interval [0,1] (BOSSERMAN and RAGADE, 1982; SALSKI, 1992). The membership functions of these fuzzy sets are mostly shaped as triangles (Figure 1). Each of them represents a qualitative expression, a linguistic term like "good" or "low". A fuzzy set A is a set of pairs:

$$
A=\left\{\left(\mu_{A}(x), x\right)\right\}, \forall x \in X
$$

where $\mu_{A}$ is the membership function of the fuzzy set $A$, which assigns to each precise element $x \in X$ the grade of its membership (PIEGAT, 2001). The procedure of the assignment of crisp input values to one or more fuzzy sets is called fuzzification.

In a fuzzy model three steps are included: fuzzification, inference and defuzzification (Figure 2) (SALSKI, 1992; TRAEGER, 1994; PIEGAT, 2001). By fuzzification the input values are transformed into memberships of fuzzy sets, which represent linguistic variables (Figure 1). In the process of inference the fuzzy sets are combined by logical, linguistic rules of the form: IF premise 1 AND premise 2 THEN conclusion, both premise and conclusion symbolizing fuzzy sets. An excerpt of the rules related to crayfish habitat quality could be: IF "occurrence of shelters" = "high" AND "diversity of depth" = "low" THEN "habitat quality" = "medium". In a fuzzy model many such rules are implemented. Their number increases exponentially with the number of inputs and the number of fuzzy sets. Therefore, it is preferable to use as few and simple input variables as possible (SALSKI, 1992; PIEGAT, 2001). If a rule is fulfilled, an activation grade for the rule conclusion is calculated, and the conclusion's membership function is modified by restricting it to a maximum equal to the activation grade. In a final step of the inference the modified membership functions of the activated conclusions are aggregated into one resulting membership function (Figure 2). There are several possible inference mechanisms, for example MIN/MAX or MAX/PROD (for details see PIEGAT, 2001). Finally, a crisp, numeric output value is generated by the defuzzification step, which is again accomplished by one out of several mechanisms, for example "centre of gravity" or "height method" (details in PIEGAT, 2001). 


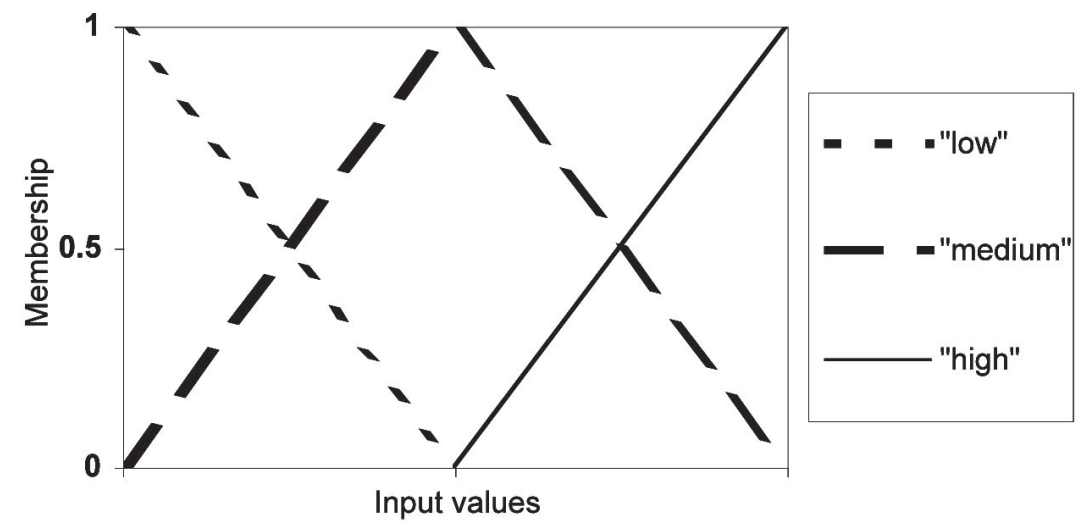

Figure 1

Example of a continuous input variable fuzzified by three fuzzy sets.

\section{Figure 1}

Exemple d'une variable d'entrée continue rendue floue par trois groupes flous.

The aim of this study is to develop a habitat suitability index for the noble crayfish Astacus astacus using fuzzy modelling. The existing database on structural stream characteristics of Hesse provided the model basis. A fuzzy model was set up to calculate the habitat suitability and produce a map of the resulting values of each stretch of the water net. This map could give hints about unknown crayfish populations, indicate appropriate habitats for restocking measures and be a support in the assessment of the consequences of river construction work, also in the context of the European Water Framework Directive.

\section{MATERIAL AND METHODS}

\section{Data on stream structure}

The structural characteristics of all rivers and streams in Hesse were examined between 1996 and 1998 by order of the Ministry of Hesse for Environment, Rural Areas and Consumers Protection (former Ministry of Hesse for Environment, Agriculture and Forestry) (BLANK et al., 2000). Assessed streams and rivers of a total length of $21,800 \mathrm{~km}$ were divided into 218,414 survey sections of $100 \mathrm{~m}$ each. Altogether 25 basic structural parameters were recorded in the field for each section. Assessed parameters do not only include morphological conditions but also take into account bankside features, riparian vegetation and land-use. Most parameters were classified using qualitative and linguistic terms. These represent the frequency or proportion of a certain feature or simply the presence of a specific property and were transformed into numbers for the use in GIS. In the normal process of stream evaluation these parameters are used to describe the structural quality of a specific stretch by a comparison with reference types representing natural or near natural conditions. For this study the coded basic parameters were utilized.

\section{Crayfish data}

The inventory of crayfish stocks in Hesse was performed by MEINEL and MOCK (2001) over a period of eight years from 1988 to 1996. It was based on questionnaires filled in by managers, fishers and anglers and on presence and absence data recorded by night viewing and trapping. Results were published in print format (scale 1: 1100,000), and they 


\section{FUZZIFICATION}

Crisp input values $(\mathrm{x})$ are transformed into memberships (in the example_A and _B) of fuzzy sets (linguistic variables, here symbolized by $A$ and $B$ )

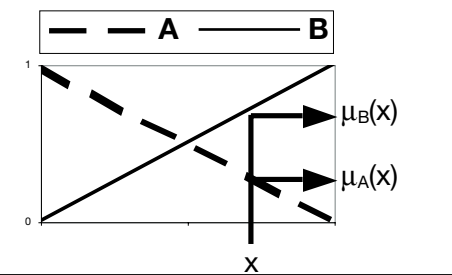

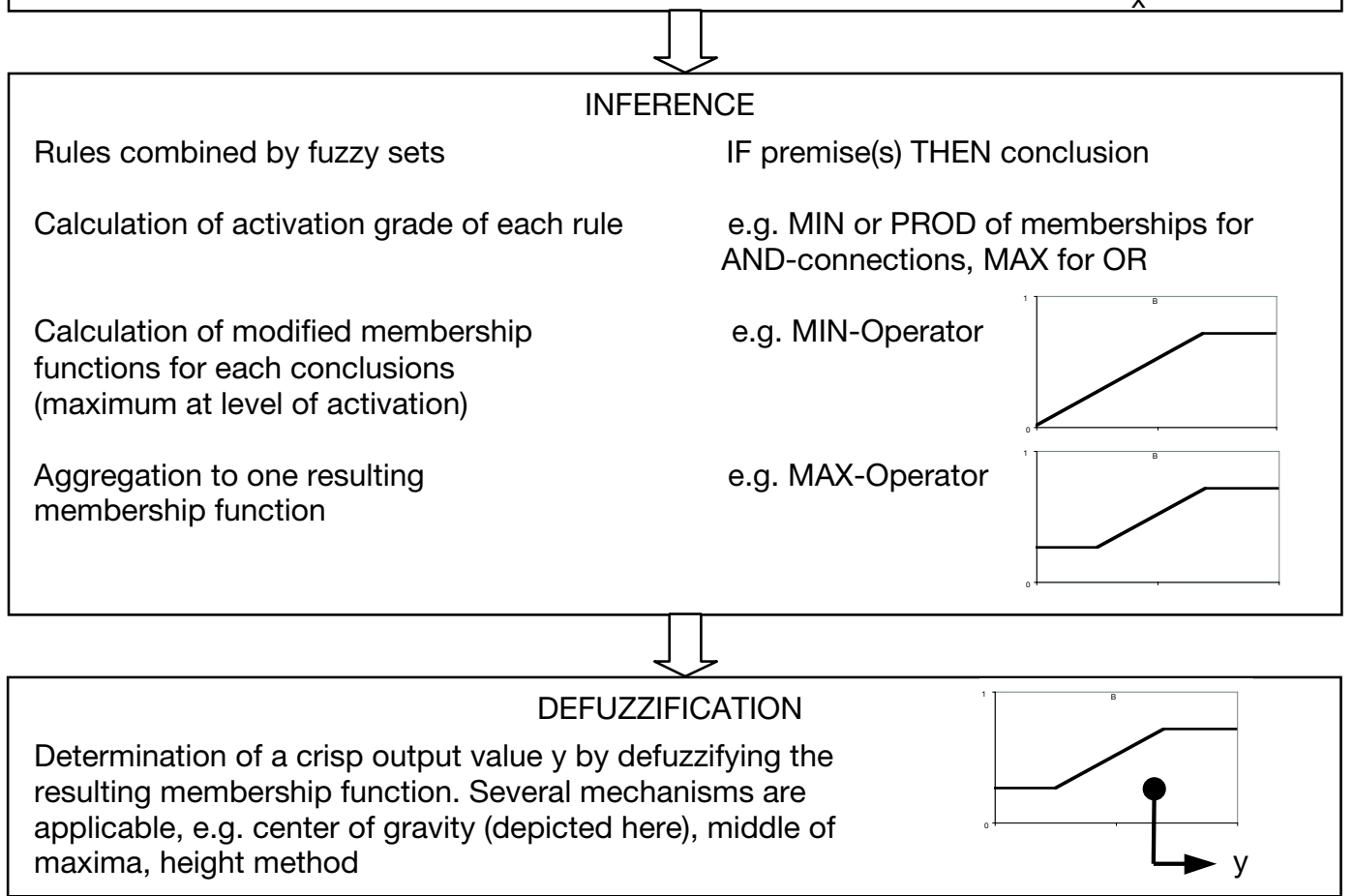

\section{Figure 2}

Process of a complete fuzzy model beginning with crisp input values $x$ and ending with a precise output value $y$.

\section{Figure 2}

Processus complet du modèle flou débutant par une valeur précise $\mathrm{x}$ et finissant par une valeur de sortie précise $y$.

were digitised for the use in the present study. A total of 185 noble crayfish populations could be assigned to specific stretches of the digital water net with reasonable certainty by using a GIS. Due to a certain degree of inaccuracy inherent in this procedure and due to missing information on the geographical expansion of each stock, a buffer with a radius of 300 metres was set up around the selected stretches. The stretches within these buffers belonging to the same stream were also counted as noble crayfish sites. All remaining watercourses in Hesse were evaluated as lacking noble crayfish populations.

\section{The statistical analysis}

Significant parameters for the occurrence of noble crayfish stocks were identified by comparing river stretches with known stocks and river stretches without known stocks. Therefore, one third of the inhabited stretches $(n=410)$ was chosen by chance and compared with all uninhabited stretches $(n=217,173)$ using a non-parametric Kolmogorov-Smirnoff test and a frequency analysis. From the initial set of significant 
parameters $(p<0.05)$ five parameters were selected to derive the fuzzy model: depth diversity, bank vegetation, special bank structures, land-use as meadows, and buffer strips. The final selection was based on assumed habitat requirements according to observations and studies by BOHL (1989), SMITH et al. (1996), BLANKE (1998), and SCHULZ (2000) and interpretable differences in the frequency analysis (Table I). For the parameters land-use (meadows) and buffer strips the mean value of both banks was used. Regarding the feature special bank structures values of the right and left differed only in $6 \%$ of the stretches and thus allowed to include only the values of the left bank as simplification.

\section{The fuzzy model}

The fuzzy model of the noble crayfish habitat quality was set up using five parameters, which are fuzzified by 2 or 3 fuzzy sets, symbolizing the linguistic terms "low", "medium", and "high". The inference block is composed of 70 rules. These rules were designed according to the results of the statistical analysis and the habitat requirements mentioned in the literature (see discussion). The mechanism used for inference was the PROD/MAX method. The conclusions of the rules are in this case not fuzzy sets but single values, called singletons. The rules were able to activate 11 of them in the interval $[0.0,1.0]$. Defuzzification resulting in the habitat suitability index was accomplished by the height method, also known as singleton method, which is easy to calculate and produces accurate results (PIEGAT, 2001). Furthermore, exclusion criteria were implemented in the model. These are parameters or specific values of parameters, which exclude the occurrence of crayfish stocks (Table II). The selection of these criteria was performed based on publications by BOHL (1989), TREFZ and GROB (1996) and BLANKE (1998). In addition, only those parameters or values were selected which appeared in less than $4 \%$ of the statistically analysed crayfish sites (Table II). If a stretch of a stream or river featured one of these exclusion criteria the habitat suitability index was set to zero. The complete model was programmed with the computer language $C$ and was run for each stretch of the water net in Hesse.

\section{RESULTS}

\section{Selection of significant structural parameters}

The Kolmogorov-Smirnoff test showed significant associations between crayfish occurrence and some structural parameters, though the differences of the frequencies for specific values between stretches inhabited and those not inhabited by noble crayfish were not obvious for all of them. Table I shows the frequencies of the coded values for the five parameters selected for the model. Regarding the parameters depth diversity (P1) and special bank structures (P3), increasing coded values represent a decreasing diversity and a decreasing amount of special structures. Regarding the parameter bank vegetation (P2), the coded values indicate deviation from natural conditions. The parameters landuse type meadows and buffer strips were quantified according to their proportion. The coded value 0 was assigned to stretches of water in which the respective parameter was not evaluated. In comparison to no-noble crayfish stretches the percentage of medium values increased in case of the parameters depth diversity (P1), bank vegetation (P2) and special bank structures (P3) when Astacus astacus was present, whereas the proportion of high values representing disturbed conditions decreased. Low values representing almost natural conditions were in some cases even more frequent at stretches without noble crayfish. For the parameters P4 and P5, representing the proportion of meadows and buffer strips (e.g. 3 corresponds to $>50 \%$ ), a significant preference for these factors by Astacus astacus was recognizable (Table I shows only the values of the right bank). Table II presents the frequency of noble crayfish sites featuring structural characteristics, which had been selected as exclusion criteria causing a habitat suitability of 0 . 
Table I

Frequency of stretches inhabited and not-inhabited by Astacus astacus featuring the specific values of parameters selected for the fuzzy model (coded value 0 = not evaluated; $-=$ value does not occur for the parameter), and level of significance (p) of the Kolmogorov-Smirnoff test.

Tableau I

Fréquence des étendues habitées ou non par Astacus astacus comportant des valeurs spécifiques pour paramètres sélectionnés pour le modèle flou (valeur codée $0=$ non évaluée, $-=$ inexistante pour le paramètre), et le niveau de signifiance ( $p$ ) du test de Kolmogorov-Smirnoff.

\begin{tabular}{l|cccccc}
\hline & $\begin{array}{c}\text { Coded } \\
\text { value }\end{array}$ & $\begin{array}{c}\text { Depth } \\
\text { diversity } \\
\text { (P1) [\%] }\end{array}$ & $\begin{array}{c}\text { Bank } \\
\text { vegetation } \\
\text { (P2) [\%] }\end{array}$ & $\begin{array}{c}\text { Special } \\
\text { bank } \\
\text { structures } \\
\text { (P3) [\%] }\end{array}$ & $\begin{array}{c}\text { Land- } \\
\text { use type } \\
\text { meadows } \\
\text { (P4) [\%] }\end{array}$ & $\begin{array}{c}\text { Buffer } \\
\text { strips } \\
\text { (P5) [\%] }\end{array}$ \\
\hline Crayfish & 0 & 5.6 & 5.6 & 5.6 & 51.7 & 77.7 \\
absent & 1 & 2.1 & 8.7 & 10.2 & 3.7 & 3.8 \\
$(\mathrm{n}=217173)$ & 2 & 10.8 & 3.2 & 6.4 & 5.9 & 3.9 \\
& 3 & 27.6 & 66.6 & 10.4 & 38.6 & 14.5 \\
& 4 & 40.6 & 7.5 & 10.1 & - & - \\
& 5 & 13.2 & 4.8 & 21.6 & - & - \\
& 6 & - & 3.5 & 35.7 & - & - \\
\hline Crayfish & 0 & 0.7 & 0.7 & 0.7 & 33.3 & 63.8 \\
present & 1 & 1.5 & 4.8 & 9.0 & 2.9 & 5.8 \\
$(\mathrm{n}=410)$ & 2 & 8.5 & 3.6 & 12.1 & 3.2 & 5.1 \\
& 3 & 41.0 & 75.1 & 18.5 & 60.7 & 25.24 \\
& 4 & 39.1 & 11.0 & 14.1 & - & - \\
& 5 & 9.2 & 3.4 & 21.8 & - & - \\
& 6 & - & 1.4 & 23.8 & - & - \\
\hline KS-Test & $\mathrm{P}$ & 0.0006 & $<0.0001$ & $<0.0001$ & $<0.0001$ & $<0.0001$ \\
\hline
\end{tabular}

\section{Habitat suitability index}

As expected, the fuzzy model produced outputs in the interval $[0.0,1.0]$ for every stretch of water in Hesse. Results for stretches without known stocks of Astacus astacus are depicted in a histogram in Figure 3. Figure 4 shows the habitat suitability indices of the crayfish sites except those included in the preceding statistical analysis to set up the model $(n=832)$. It becomes obvious that in both cases the proportion of the suitability index value zero was rather high and occurred at $31.1 \%$ of all stretches of water in Hesse, though slightly less frequent at noble crayfish sites with $17.6 \%$. Excluding the value zero, the most frequent habitat suitabilities occurred around 0.8 at no-noble crayfish and around 0.85 at noble crayfish stretches, showing that mostly high suitability indices were calculated by the model, whereas low values around 0.1 were almost not present. Generally, a slight tendency to higher values was observed in streams inhabited by Astacus astacus. However, using a T-test to compare the results except the value zero a significant difference was detected between stretches with and without known crayfish stocks $(p<0.001)$. If zero values are excluded from the analysis, then $90 \%$ of the noble crayfish stretches were classified by a habitat suitability index $>0.56$, while this index was only exceeded in $78.6 \%$ of the no-noble crayfish sites. The results of the model could be 


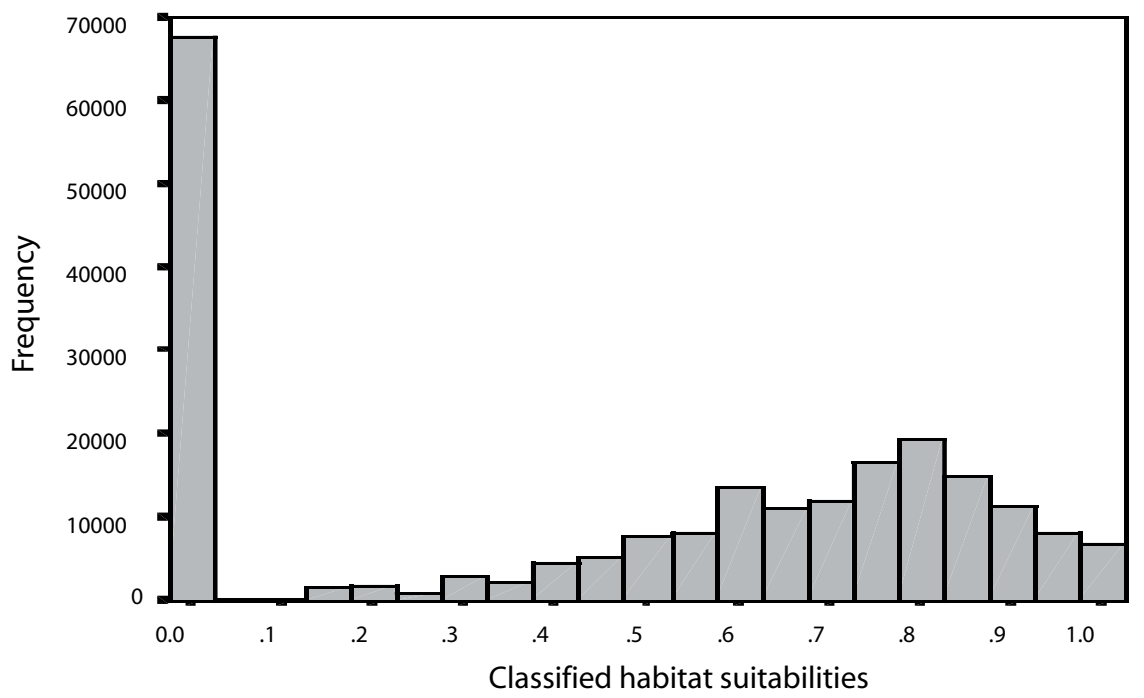

Figure 3

Histogram of the classified habitat suitability indices at stretches of water without known stocks of $A$. astacus.

\section{Figure 3}

Histogramme des indices de qualité d'habitat classés sur les sections de cours d'eau ne possédant pas de population d'A. astacus.

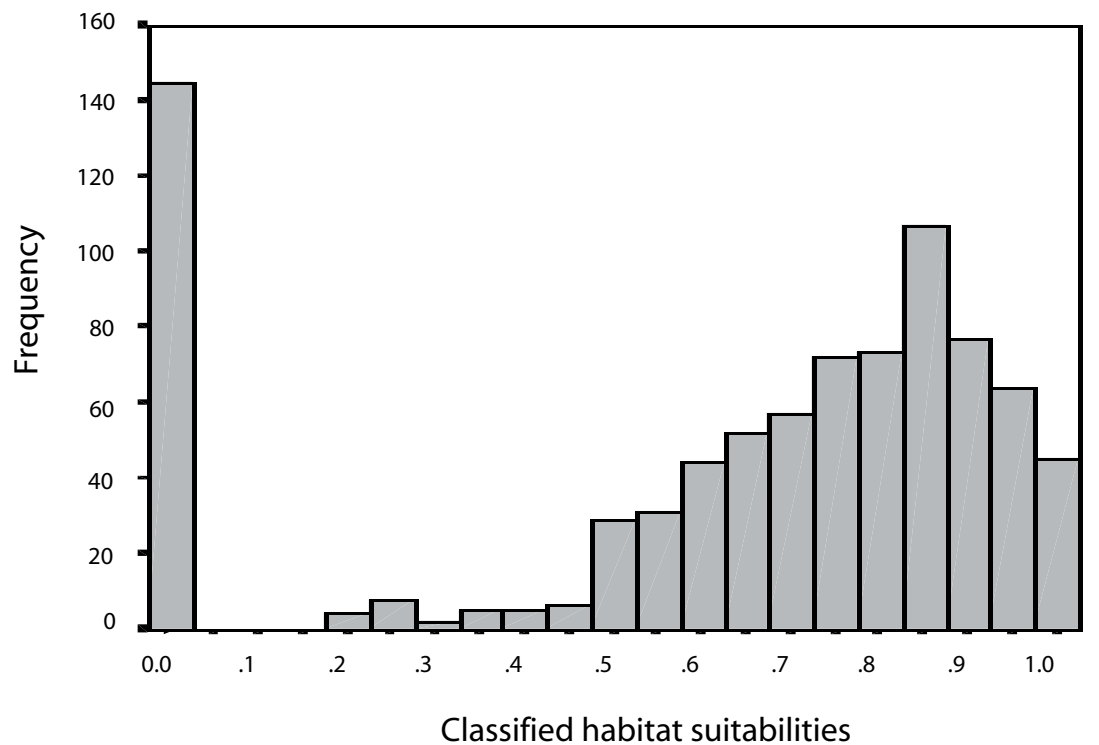

Figure 4

Histogram of the classified habitat suitability indices at stretches of water inhabited by $A$. astacus.

Figure 4

Histogramme des indices de qualité d'habitat classés sur les sections de cours d'eau habitées par $A$. astacus. 


\section{Table II}

Exclusion criteria causing a habitat suitability of 0 and the respective relative frequencies at the analysed crayfish sites.

Tableau II

Critère d'exclusion causant une qualité d'habitat de 0 et fréquences respectives relatives aux sites à écrevisses analysés.

\begin{tabular}{llc}
\hline \multicolumn{1}{c}{ Parameter } & \multicolumn{1}{c}{ Evaluation } & $\begin{array}{c}\text { Frequency at } \\
\text { crayfish sites [\%] }\end{array}$ \\
\hline Situation of the waters & Completely piped, in town & 0.24 \\
Situation of the waters & Completely piped, open country & 0.48 \\
Situation of the waters & Dried out (4 possible cases) & 0.00 \\
Pipe & $20-50$ m, sediment & 0.00 \\
Pipe & $>50$ m, sediment & 0.00 \\
Pipe & $2-50$ m, without sediment & 0.24 \\
Pipe & $>50$ m, without sediment & 0.00 \\
Type of profile & Artificial, rectangular & 2.88 \\
Bottom substrate & Mud, sludge & 3.84 \\
Bottom substrate & Boulders, gravel, stones & 0.00 \\
Bottom substrate & Pure boulder accumulation & 0.00 \\
Bottom substrate & Bedrock & 0.00 \\
River bed constructions & Solid, with sediment $(>50 \%)$ & 2.64 \\
River bed constructions & Solid, without sediment $(>50 \%)$ & 0.72 \\
River bed constructions & Solid, without sediment (10-50\%) & 2.64 \\
Bank constructions left & Concrete, masonry, cobbles $(>50 \%)$ & 1.20 \\
Bank constructions right & Concrete, masonry, cobbles (>50\%) & 0.96 \\
\hline
\end{tabular}

implemented in the digital water net of a GIS. Thus it was possible to generate a map of rivers and streams in Hesse, which displayed the assigned habitat suitability for the noble crayfish of every stretch of water and thus made suitable and not suitable sites visible.

\section{DISCUSSION}

Although the comparison of stretches with known noble crayfish occurrence and sites with assumed absence of the noble crayfish revealed significant differences in a number of parameters, most of these differences could hardly be interpreted as a habitat preference. The selection of parameters to be included in the habitat suitability model was finally based on expert knowledge. SKURDAL et al. (1988), BOHL (1989), TREFZ and GROB (1996), BLANKE (1998) and BOHL, KELLER and OIDTMANN (2001) highlighted the significance of the structural quality of waters in respect of the occurrence of $A$. astacus. Depth diversity is a main characteristic of crayfish habitats and may be essential because of age specific preferences (SKURDAL et al., 1988; BOHL, 1989; BLANKE, 1998; ENGLUND and KRUPA, 2000). The riparian vegetation is on the one hand important as a food source. On the other hand, the extension of roots into the water provides protection in time of high 
flow and nursery areas for younger crayfish (SMITH et al., 1996). Special bank structures like overhanging boughs and undercuttings of the bank increase the diversity of the habitats with positive effects on crayfish occurrence (SKURDAL et al., 1988; SMITH et al., 1996; BLANKE, 1998; BOHL, KELLER and OIDTMANN, 2001; BROQUET, THIBAULT and NEVEU, 2002). Studies by BOHL (1989) and SCHULZ (2000) indicate the positive effect of the land-use types forest and meadows. Finally, buffer strips increase the structural diversity of the banks, could provide shade and might act as a filter for nutrients and pesticides (BOHL, 1989; SMITH et al., 1996; BLANKE, 1998).

The results of the present habitat suitability model do not indicate an obvious structural difference between crayfish and non-crayfish sites. As can be seen for individual parameters, inhabited stretches revealed only a slight tendency towards better habitat suitability values, which are also the most frequently calculated results. A causal explanation of this observation is hampered by potential impreciseness in the localisation of the crayfish sites. During the inventory of crayfish sites in Hesse, crayfish distribution was not matched to the mapping system used for the structural assessment of waters. MEINEL and MOCK (2001) presented the crayfish distribution as point data. Due to missing data on the geographical expansion of each stock, an exact allocation of crayfish sites to individual stretches of streams was not possible in the present study. As an alternative approach, all stretches of the same stream within a range of $300 \mathrm{~m}$ around the data point representing the crayfish site were defined as inhabited. This approach inevitably resulted in a certain frequency of falsely classified stretches. An exact localisation is needed to derive reliable conclusions on the habitat preference of the noble crayfish. However, the present study indicates that Astacus astacus can potentially inhabit streams and rivers in a broad range of physical structures. The distribution of the noble crayfish might be additionally or predominantly affected by factors not included in the present habitat suitability model. Furthermore, the colonisation of suitable habitats is inhibited due to a strong fragmentation. In contrast, NAURA and ROBINSON (1998) demonstrated that the occurrence of the European white-clawed crayfish (Austropotamobius pallipes) in Britain could be predicted from map derived information as well as from data on the stream structure. The authors used a logistic regression on variables of the River Habitat Survey (RHS), a comprehensive database of the physical structure of British rivers including more than 100 environmental variables (RAVEN et al., 1998). A first model contained 10 variables relating to channel vegetation, bank and channel structure. A second model was set up using 11 variables relating to bank and channel structure and additionally to tree features. Predictions of crayfish presence and absence were significant for both models, in which the ability of predicting crayfish presence was higher than of predicting crayfish absence. However, the average distance between RHS sites, where data on the physical structure was available, and crayfish sites was $1.7 \mathrm{~km}$ and therefore definitely higher than in the present study. It is questionable whether RHS sites represent the physical structure of the crayfish sites.

Fuzzy logic was first assumed to be useful for ecological modelling in the 1980s (BOSSERMAN and RAGADE, 1982) and especially in the 1990s (SALSKI, 1992). At that time it was also applied to habitat modelling. SCHULTZ and WIELAND (1995) did not use a complete fuzzy model, but based calculations on logical combinations of fuzzy sets . WIELAND (1997) described an application of fuzzy logic using a complete model to calculate the habitat suitability, and LUTZE, WIELAND and SCHULTZ (1999) even used data from a GIS for modelling. But they did not apply their approaches to aquatic organisms. Their general conclusion was that fuzzy logic was a very helpful method for habitat modelling. This point of view is confirmed by the present study, because the model itself and its mechanism work quite well. The results reflect exactly the difference between stretches inhabited and those not inhabited by noble crayfish, which is already inherent in the data on structural characteristics. 


\section{CONCLUSION}

For the conservation of European indigenous crayfish species like Astacus astacus the preservation of suitable habitats is vital. A habitat suitability index based on fuzzy modelling is a useful tool in this process, helping to plan and perform habitat restorations and restocking measures. The present study shows that fuzzy modelling is an adequate method to achieve a habitat suitability index for indigenous crayfish species. But it also reveals the necessity of spatially exact data as input, which can be correctly localised and evaluated. Further improvements of the model are possible by including additional parameters representing the anthropogenic impact, the impact of non-indigenous crayfish species and crayfish plague. A combination of fuzzy modelling and neural networks is also a considerable possibility to produce more reliable results, though generally the way presented here is adequate to predict crayfish occurrences or suitable habitats.

\section{ACKNOWLEDGEMENTS}

We sincerely thank Prof. Dr. Werner MEINEL for contributing information on crayfish distribution in Hesse. The digital data on structural quality was provided by the Ministry of Hesse for Environment, Rural Areas and Consumers Protection.

\section{REFERENCES}

BLANKE D., 1998. Flußkrebse in Niedersachsen. Informationsdienst Naturschutz Niedersachsen, 18, 146-174.

BLANK M., GIESLER K., NIEHOFF N., WINKENS M., 2000. Gewässerstrukturgüte in Hessen 1999 - Erläuterungsbericht. Hessisches Ministerium für Umwelt, Landwirtschaft und Forsten, Wiesbaden, $52 \mathrm{p}$.

BOHL E., 1989. Ökologische Untersuchungen an ausgewählten Gewässern zur Entwicklung von Zielvorstellungen des Gewässerschutzes - Untersuchungen an Flusskrebsbeständen (Kurzfassung). Bayerische Landesanstalt für Wasserforschung, Wielenbach, $87 \mathrm{p}$.

BOHL E., KELLER M., OIDTMANN B., 2001. Flusskrebse in Bayern - Information für Naturschutz, Wasserwirtschaft, Fischerei, Teichwirtschaft, Fisch- und Aquarienhandel, Gastronomie. Landesfischereiverband Bayern e.V., Bayerisches Landesamt für Wasserwirtschaft, $36 \mathrm{p}$.

BOSSERMAN R.W., RAGADE R.K., 1982. Ecosystem analysis using fuzzy set theory. Ecological Modelling, 16, 191-208.

BROQUET T., THIBAULT M., NEVEU A., 2002. Distribution and habitat requirements of the white-clawed crayfish, Austropotamobius pallipes, in a stream from the Pays de Loire region, France: an experimental and descriptive study. Bull. Fr. Pêche Piscic., 367, 717-728.

ENGLUND G., KRUPA J.J., 2000. Habitat use by crayfish in stream pools: influence of predators, depth and body size. Freshwater Biology, 43, 75-83.

LUTZE G., WIELAND R., SCHULTZ A., 1999. Habitatmodelle für Tiere und Pflanzen Instrumente zur integrativen Abbildung und Analyse von Lebensraumansprüchen mit direktem Bezug zur Landschaftsstruktur und zur Landnutzung. In Blaschke T. (ed.), Umweltmonitoring und Umweltmodellierung: GIS und Fernerkundung als Werkzeug einer nachhaltigen Entwicklung, 223-236.

MEINEL W., MOCK T., 2001. Vorkommen der zehnfüßigen Krebse in Hessen Bestandssituation, Verbreitung, Gefährdung und Schutz. Hessisches Ministerium für Umwelt, Landwirtschaft und Forsten, Wiesbaden, $72 \mathrm{p}$. 
NAURA M., ROBINSON M., 1998. Principles of using River Habitat Survey to predict the distribution of aquatic species: an example applied to the white-clawed crayfish Austropotamobius pallipes. Aquatic Conservation: Marine and Freshwater Ecosystems, 8, 515-527.

PIEGAT A., 2001. Fuzzy Modelling and Control. Physica-Verlag, Heidelberg, New York, $728 \mathrm{p}$.

RAVEN P.J., BOON P.J., DAWSON F.H., FERGUSON A.J.D., 1998. Towards an integrated approach to classifying and evaluating rivers in the UK. Aquatic Conservation: Marine and Freshwater Ecosystems, 8, 383-393.

SALSKI A., 1992. Fuzzy knowledge-based models in ecological research. Ecological Modelling, 63, 103-112.

SCHULZ R., 2000. Status of the noble crayfish Astacus astacus (L.) in Germany: monitoring protocol and the use of RAPD markers to assess the genetic structure of populations. Bull. Fr. Pêche Piscic., 356, 123-138.

SCHULTZ A., WIELAND R., 1995. Die Modellierung von biotischen Komponenten im Rahmen von Agrarlandschaften. Archiv für Naturschutz und Landschaftsforschung, 34, 79-98.

SCHULZ H.K., SMIETANA P., SCHULZ R., 2002. Crayfish occurrence in relation to landuse properties: implementation of a geographic information system (GIS). Bull. Fr. Pêche Piscic., 367, 861-872.

SMITH G.R.T., LEARNER M.A., SLATER F.M., FOSTER J., 1996. Habitat features important for the conservation of the native crayfish Austropotamobius pallipes in Britain. Biological Conservation, 75, 239-246.

SKURDAL J., FJELD E., HESSEN D.O., TAUGBØL T., DEHLI E., 1988. Depth distribution, habitat segregation and feeding of the crayfish Astacus astacus in Lake Steinsfjorden. Nordic J. Freshw. Res., 64, 113-119.

SKURDAL J., TAUGBØL T., 1994. Biology, culture and management of the noble crayfish Astacus astacus L. Dr. philos. Thesis, University of Oslo, Norway, $300 \mathrm{p}$.

TRAEGER D.H., 1994. Einführung in die Fuzzy-Logik. 2. Aufl., B.G. Teubner, Stuttgart, $176 \mathrm{p}$.

TREFZ B., GROß H., 1996. Populationsökologische Untersuchung zweier Edelkrebsvorkommen Astacus astacus (Linnaeus, 1758) als Grundlage für den Artenschutz. Natur und Landschaft, 71 (10), 423-429.

VIGNEUX E., THIBAULT M., MARNELL F., SOUTY-GROSSET C., 2002. National legislation, EU directives and conservation. Bull. Fr. Pêche Piscic., 367, 887-898.

WIELAND R., LUTZE G., HOFFMANN J., 1996. Fuzzy-Methoden und Neuronale Netze in der Landschaftsmodellierung. In Keller H.B., Grützner R., Hoffmann R. (eds.), 6. Treffen des AK Werkzeuge für Simulation und Modellbildung in Umweltanwendungen, Forschungszentrum Karlsruhe $\mathrm{GmbH}$, 50-59.

WIELAND R., 1997. Habitatmodellierung biotischer Komponenten. Archiv für Naturschutz und Landschaftsforschung, 35, 227-237. 